\title{
A NEW SERIES OF 1-PHENYLPYRAZOLE PEPTIDOMIMETICS
}

\author{
Luciene M. F. Santos', Antonio J. Alves', Dalci J. Brondani', Antonio R. de Faria \\ Antonio C. C. Freitas ${ }^{2}$. José G. de Lima ${ }^{3}$. Ana C. Lima Leite ${ }^{1 *}$ \\ 'Laboratorio de Tecnologia Quimico-Farmaceutica (LTQF) / Laboratório de Planejamento, Avaliação e Síntese de \\ Fármacos (LABSINFA) - Faculdade de Farmácia - Universidade Federal de Pernambuco. Prof. Artur Sá S/N, CDU, \\ 50740-520, Recife, Pernambuco - Brasil \\ aclb02@elogica.com.br \\ ${ }^{2}$ Laboratorio de Quimica Medicinal, Faculdade de Farmacia - Universidade Federal Fluminense \\ 'Departamento de Fármacos - Universidade Federal do Rio de Janeiro.
}

\begin{abstract}
A facile and efficient method for the synthesis of a new series of 1-phenylpyrazole peptidomimetics $6 \mathrm{a}-\mathrm{f}$ is described. Peptide bond formation between the 1-phenylpyrazole unsaturated carboxylic acid and the amino acid residue has been achieved using benzotriazolyloxy-tris(dimethylamino) phosphonium hexafluorophosphate (BOP) reagent and triethylamine (TEA). This strategy was found to be successful for obtaining the pyrazole peptidomimetics.
\end{abstract}

\section{Introduction}

The pyrazol nucleus in general and its chemistry have caught widespread attention due to outstanding biological activities as antipyretic, analgesic and anti-inflammatory drugs (la-c). A pyrazole ring system represents a thermally stable, aromatic ring system which resists ring opening. Although very few pyrazole derivatives occur naturally, many are pharmacologically active $(2,3)$. It has been shown that therapeutically active agents linked to small peptides or amino acid residues, reduce toxicity and enhance their therapeutic effects $(4,5,6)$. It is supposed that an amino acid transport system in the cell can be exploited to deliver the pyrazole nucleus to target cells for the drug activity.

Considering the potential of this pyrazole ring system, we undertook the synthesis of phenylpyrazole 6a-f employing the classical method of peptide synthesis. This paper reports the

\footnotetext{
- To whom correspondence should be addressed
} 
strategy of synthesis of small compounds and the verification of their structures by spectroscopic means and elemental analysis. The compounds described herein constitute a set of potentially useful building blocks in the synthesis of modified peptides.

\section{Synthesis of the compounds}

To start the synthesis, the formylation of 1-phenylpyrazole 1 at C-4 was carried out using the Vilsmeier-Haack conditions (7). The malonic acid condensation of this aldehyde 2 was realized in pyridine:piperidine resulting in a compound 3.

The peptidomimetic heterocyclic derivatives were synthesized from Boc-protected L-amino acids. The synthetic routes were applied on appropriately protected lipophilic (phenylalanine, alanine, valine, leucine) and acidic (aspartic and glutamic) amino acids. The amino acids were firstly amidified. The carboxylic acid function of $\underline{4}$ was treated with isobutyl chloroformate in the presence of triethylamine and ammonium hydroxyde in order to obtain the desired amide in good yield. We have chosen using the aspartic and glutamic amino acids so the carboxylic acid function of the side chain is protected by a benzyl ester.

The expected peptidimimetic derivatives $6 \mathrm{a}-\mathrm{f}$ have been synthesized by condensation with 1-phenylpyrazole unsaturated carboxylic acid 3 with $5 \underline{a-f}$ using benzotriazolyl-N-oxy-tris (dimethilamino)phosphonium hexafluorophosphate (BOP) to activate the carboxylic acid function by the generation of a highly reactive 1-hydroxybenzotriazole ester of the carboxyl component in its anionic form (8a-d) (scheme). The phenylpyrazole derivatives were obtained in $35-70 \%$ yield.

All compounds present characteristics of ${ }^{1} \mathrm{H}-\mathrm{NMR}$ for $\mathrm{NH}_{2}$ and $\mathrm{NH}$ moiety and the proton linked to quiral carbon. Two singlets for $\mathrm{NH}_{2}$ broaded has shown nonequivalent protons. For the $\mathrm{NH}$ a characteristic duplet has shown a coupling constant with $\mathrm{CH}$ quiral. Different chemical shift groups next to chiral center are observed. The phenomenon is more pronounced with bulky substituents. The IR spectra showed a N-H stretching asymmetric, band around $3377 \mathrm{~cm}^{-1}$ and symmetric, $3300 \mathrm{~cm}^{-1}$, overlap $\mathrm{C}=\mathrm{O}$ stretching, amide $\mathrm{I}$ band around $1641 \mathrm{~cm}^{-1}$, and $\mathrm{C}=\mathrm{N}$ stretching band at $1620 \mathrm{~cm}^{-1}$. The analytical data and chemical shifts of the compounds are given in Tables I and II. 


\section{Scheme}

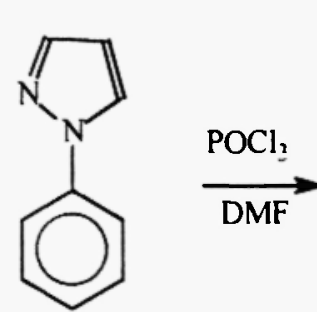

1

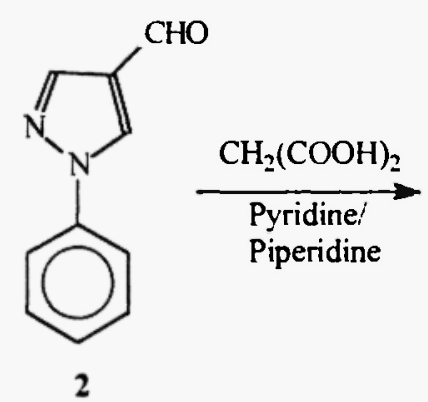

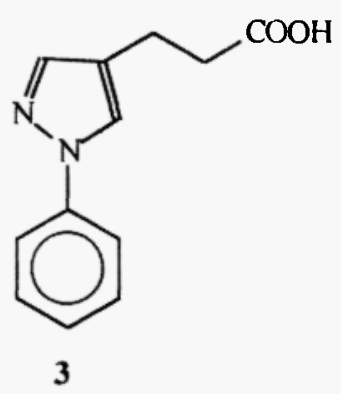

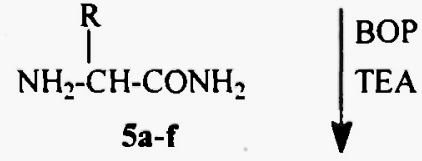

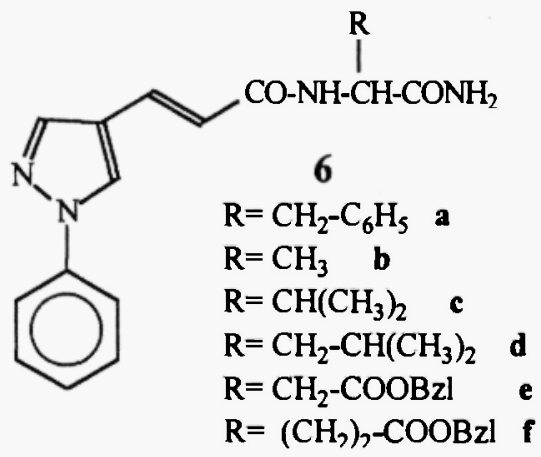

Table I- Analytical data of phenylpyrazole derivatives

\begin{tabular}{|c|c|c|c|c|c|c|c|c|c|c|c|}
\hline \multirow[t]{2}{*}{$\overline{\text { Compound }}$} & \multirow{2}{*}{$\begin{array}{l}\text { M.p. } \\
{\left[{ }^{\circ} \mathrm{C}\right]^{a}}\end{array}$} & \multirow{2}{*}{$\begin{array}{l}\text { Yield } \\
{[\%]}\end{array}$} & \multirow[t]{2}{*}[\alpha]{$_{D}$} & \multirow[t]{2}{*}{$R_{f}^{b}$} & \multirow{2}{*}{$\begin{array}{l}\text { Molecular } \\
\text { Formula }\end{array}$} & \multirow[b]{2}{*}{$\mathrm{C}$} & \multicolumn{2}{|c|}{ Calc. $(\%)$} & \multicolumn{2}{|c|}{ Found } & \multirow[b]{2}{*}{$\mathrm{N}$} \\
\hline & & & & & & & $\mathrm{H}$ & $\mathbf{N}$ & $\mathrm{C}$ & $\mathrm{H}$ & \\
\hline $6 \mathbf{a}$ & 232 & 63.3 & $-22,1$ & $0.3 \mathrm{~A}$ & $\mathrm{C}_{21} \mathrm{H}_{20} \mathrm{~N}_{4} \mathrm{O}_{2}$ & 76.8 & 6.13 & 17.0 & 76.6 & 6.11 & 16.9 \\
\hline $6 b$ & $162-4$ & 35.6 & 25.3 & $0.39 \mathrm{~B}$ & $\mathrm{C}_{15} \mathrm{H}_{16} \mathrm{~N}_{4} \mathrm{O}_{2}$ & 71.4 & 6.39 & 22.2 & 71.2 & 6.4 & 22.3 \\
\hline $6 c$ & $252-4$ & 75.3 & 78,1 & $0.3 \mathrm{~A}$ & $\mathrm{C}_{17} \mathrm{H}_{20} \mathrm{~N}_{4} \mathrm{O}_{2}$ & 72.8 & 7.19 & 19.9 & 72.6 & 7.2 & 20.0 \\
\hline 6d & $197-9$ & 52.45 & 39,3 & $0.3 \mathrm{C}$ & $\mathrm{C}_{18} \mathrm{H}_{22} \mathrm{~N}_{4} \mathrm{O}_{2}$ & 73.4 & 7.53 & 19.0 & 73.2 & 7.54 & 19.1 \\
\hline $6 e$ & $168-9$ & 51.36 & 15,7 & $0.68 \mathrm{~B}$ & $\mathrm{C}_{23} \mathrm{H}_{22} \mathrm{~N}_{4} \mathrm{O}_{4}$ & 77.9 & 6.25 & 15.8 & 77.6 & 6.2 & 15.6 \\
\hline $6 f$ & $157-9$ & 76.42 & 12,2 & $0.3 \mathrm{C}$ & $\mathrm{C}_{24} \mathrm{H}_{24} \mathrm{~N}_{4} \mathrm{O}_{4}$ & 78.2 & 6.56 & 15.2 & 78.1 & 6.55 & 15.0 \\
\hline
\end{tabular}

'Crystallized from Ethyl acetate/ether/ hexane. 'Solvent systems: A(AcOET), B(AcOET/hexane, 8:2), C(AcOET/hexane, 7:3). 
Table II- IR and NMR Spectral data

\begin{tabular}{|c|c|c|c|c|c|}
\hline \multirow{3}{*}{$\begin{array}{l}\text { Compound } \\
6 a\end{array}$} & \multirow{3}{*}{$\begin{array}{l}\text { (N-Hasym) } \\
3377\end{array}$} & \multicolumn{3}{|c|}{$\mathrm{IR} \mathrm{cm}^{-i}(\mathrm{KBr})$} & \multirow{2}{*}{$\begin{array}{c}\text { 'H-NMR } \\
\delta p p m\left(\mathrm{DMSOd}_{6}\right)\end{array}$} \\
\hline & & (NHsym) & $(C=0$ amic & en $\mathrm{C}=\mathrm{N}$ & \\
\hline & & 3303 & 1643 & 1619 & $\begin{array}{l}3.36(\mathrm{~d}, 2 \mathrm{H}), 4.54-4.57(\mathrm{~m}, 1 \mathrm{H}), 7.3-7.9(\mathrm{~m}, 10 \mathrm{H}), 4.4(1 \mathrm{H}), 6.49-6 \\
8.4(\mathrm{~d}, 2 \mathrm{H})\end{array}$ \\
\hline 6b & 3394 & 3288 & 1672 & 1604 & $\begin{array}{l}2.5(2 \mathrm{H}), 4.31-4.36(\mathrm{q}, 1 \mathrm{H}), 1.25(\mathrm{~d} .3 \mathrm{H}), 3.35(1 \mathrm{H}) \\
6.39-6.58(\mathrm{t}, 2 \mathrm{H}), 7.33-8.13(\mathrm{~m}, 5 \mathrm{H}), 8.77-8.79(\mathrm{~d} 2 \mathrm{H})\end{array}$ \\
\hline $6 c$ & 3376 & 3297 & 1659 & 1621 & $\begin{array}{l}1.82-1.89(\mathrm{~m}, 3 \mathrm{H}), \quad 4.07-4.12(\mathrm{q}, \quad 1 \mathrm{H}), \quad 0.72-0.74(\mathrm{~d}, \quad 6 \mathrm{H}), \quad 3.41 \\
6.54(\mathrm{t}, 2 \mathrm{H}), 7.16-7.87(\mathrm{~m}, 5 \mathrm{H}), 8.05-8.1(\mathrm{~d} .2 \mathrm{H})\end{array}$ \\
\hline $6 d$ & 3381 & 3305 & 1655 & 1621 & $\begin{array}{l}1.5(2 \mathrm{H}), 4.35-4.37(\mathrm{q}, 1 \mathrm{H}), 1.58-1.6(\mathrm{t}, 2 \mathrm{H}), 0.88-0.93(\mathrm{~m}, 1 \mathrm{H}), 0.85 \\
0.51-0.57(\mathrm{t}, 2 \mathrm{H}), 7.3-8.7(\mathrm{~m}, 5 \mathrm{H}), 8.75-8.77(\mathrm{~d}, 2 \mathrm{H})\end{array}$ \\
\hline $6 e$ & 3383 & 3313 & 1661 & 1624 & $\begin{array}{l}2.48(2 \mathrm{H}), 4.74-4.79(\mathrm{q}, 1 \mathrm{H}), 2.60-2.64(\mathrm{~d}, 2 \mathrm{H}), 5.12(\mathrm{~s}, 2 \mathrm{H}), 7.32-7 \\
6.52-6.57(\mathrm{t}, 2 \mathrm{H}), 8.40-8.42(\mathrm{~d}, 2 \mathrm{H})\end{array}$ \\
\hline $6 f$ & 3385 & 3315 & 1653 & 1619 & $\begin{array}{l}1.66(2 \mathrm{H}), 4.35-4.37(\mathrm{q}, 1 \mathrm{H}), 3.42(1 \mathrm{H}), 2.39-2.50(\mathrm{~m}, 2 \mathrm{H}), \\
2.51-2.54(\mathrm{t}, 2 \mathrm{H}), 5.09(\mathrm{~s}, 2 \mathrm{H}), 8.29-8.32(\mathrm{t}, 2 \mathrm{H})\end{array}$ \\
\hline
\end{tabular}

\section{Conclusions}

The compounds synthesized in the present work represent a novel class of pseudopeptides. The reactions producing 1-phenylpyrazole having a pseudopeptide chain are versatile and can be performed starting from most of the natural amino acids. The overall yields of the pseudopeptides are satisfactory and the synthetic sequences are short and facile. The reaction conditions used are mild for the protected groups.

\section{Experimental}

All melting points were determined by using a Thomas Hoover apparatus and are incorrected. IR spectra were obtained by using $\mathrm{KBr}$ pellets. ${ }^{1} \mathrm{H}$ NMR spectra were measured with a Varian UNITYplus-300 MHz NMR spectrophotometer using DMSO- $\mathrm{d}_{6}$ as solvent as tetramethylsilane like an internal standard. Thin-layer chromatography (TLC) was carried out on silica gel plates having fluorescence indicator $F_{254}(0.2 \mathrm{~mm}, \mathrm{E}$. Merck); the spots were visualized with UV light, and by spraying with a $2 \%$ ethanol solution of ninhydrin or charing reagent. Column chromatography was performed on silica using Kiesegel 60 (230-400 mesh, E. Merck) with ethyl acetate/hexane. Optical rotations were measured at $20^{\circ} \mathrm{C}$, using DMSO as solvent in a $10 \mathrm{~cm}$ cell, and $c$ is expressed in $\mathrm{g} / 100 \mathrm{~mL}$. The elemental analyses were performed in a PE- 2400 apparatus. Protected amino acids 
(Boc and Obzl), were purchased from Bachem (Switzerland) or Propetide (vert le Petit, France). All reagents used in the present work were of analytical grade.

$\mathbf{N}$-Phenylpyrazole $\underline{1}$ : Was prepared in $85 \%$ yield by the previously described procedure $(10)$.

4-Formyl-1- phenylpyrazole 2 : was obtained in $80 \%$ yield from 1 , as crystals, $\mathrm{mp} 83-84^{\circ} \mathrm{C}$ by using the modified conditions described by Finar ${ }^{7}$. Spectroscopic data were identical to those previously reported (7).

(E)-3-(1-phenylpyrazol-4-yl)prop-2enoic Acid 3: a mixture of malonic acid (12.4 g, 119.2 mmols) and pyridine $(30 \mathrm{ml}, 58.1 \mathrm{mmoles})$ was treated with 4-Formyl-1- phenylpyrazole $(10 \mathrm{~g}, 58.1$ mmoles) and $1 \mathrm{ml}$ of piperidine. The reaction mixture was heated at $115^{\circ} \mathrm{C}$.for 4 hours, and cooled. After acidification, the white solid product was collected by filtration, crystallized from ethanol to give the analytical sample, $\mathrm{mp} 185-186^{\circ} \mathrm{C}\left(\right.$ lit $\left.186-7^{\circ} \mathrm{C}\right)(11)$.

Procedure for the protection of the $\mathrm{C}$-terminus moiety of the amino acids 5a-f: To a cold ( -10 $0^{\circ} \mathrm{C}$ ) solution of $\mathrm{N}$-Boc-Amino acid $(3.0 \mathrm{mmol})$ in dimethylformamide, were successively added isobutyl chloroformate $(3.0 \mathrm{mmol})$ and ammonium hydroxide dropwise for $20 \mathrm{~min}$. After that, the mixture was stirred at room temperature during $\mathrm{lh}$. Water was added and the pure product was easily isolated by filtration and dried.

General Procedure for the Synthesis of 1-Phenylpyrazoles Containing Pseudopeptide Moiety 6a-f: To the Boc-Amino acylamide, trifluoroacetic acid was added and was left to stand at room temperature, during half an hour. After that, the mixture was concentrated in vacuo, and gave a white powder after trituration with ether. The pure product was easily isolated by filtration and dried. TFA-Amino Acylamide (2.6mmol) was dissolved in DMF (10mL) containing 3 (2.6 mmoles) and BOP $(2.6 \mathrm{mmol})$. The solution was cooled in an ice bath, and TEA $(0.7 \mathrm{~mL})$ was added to it. The preparation was left to stand for 4 hours at room temperature. Afterwards, a saturated solution of sodium bicarbonate was added under stirring, followed by ethyl acetate $(50 \mathrm{~mL})$. The organic layer was washed several times with sodium bicarbonate $(50 \mathrm{~mL})$, water $(50 \mathrm{~mL}), 1 \mathrm{M}$ citric acid $(50 \mathrm{~mL})$, water $(50 \mathrm{~mL})$, dried over sodium sulfate and concentrated in vacuo. The residue was purified by silica gel column chromatography with ethyl acetate-hexane (6a: 5/5, 6b: 7/3, 6c: 8/2), ethyl acetate (6d) and ethyl acetate-methanol 9/1 (6e) as solvent, and gave a white powder after being crystallized with diethyl ether-hexane.

\section{Aknowledgments}

The financial support from the "Conselho Nacional de Desenvolvimento Científico e Tecnologico" $(\mathrm{CNPq})$, the "Fundação de Amparo a Ciencia do Estado de Pernambuco" (FACEPE) is gratefully acknowledged. We also thank Dr. Jean Martinez - LAPP (Laboratoire des Amino acides, Peptides et Proteines-CNRS, Montpellier, France) for providing amino acids. The authors thank the Departamento de Química Fundamental, Universidade Federal de Pernambuco (UFPE) for recording the 'H-NMR and IR spectra of all compounds. 


\section{References}

(1) a) E. J. Barreiro and A. C.C. Freitas. J. Heterocyclic Chem., 29, 407-501 (1992). b) A. C. C Freitas., E. J., Barreiro, A. L. Pereira,. Quimica Nova, , 18(2) 138143 (1995). c) I. A. F. B. Silveira. L. G. A. Paulo, L. P. Miranda. S. O. Rocha, A. C.C. Freitas, E. J. Barreiro, J. Pharm. Pharmacol., 45, 646-649 (1993).

(2) J. Elguero, in Comprehensive Heterocyclic Chemistry, Vol 5, part 5A. A. R. Katritzky, C. W. Rees and K. T. Potts, eds, Pergamon Press, New York, 1984, p.167.

(3) T. C. Jacobs, Heterocyclic Compounds, Vol 5, R. C. Elderfield. ed., John Wiley and Sons. Inc, pp 45-66, 1957.

(4) S. K. Aggarwal, S. R. S. Gogu, R. S. Rangan and K. Agrawal, J. Med. Chem., 1990, 33, p. 1505-10.

(5) D. Haines, R. Fuller, S. Ahmad, D. Vistica, and V. Marquez, J. Chem. Soc., 30, p. 542-7 (1987).

(6) A. Philip, J. Kepler, B. Johnson and F. Carrol, J. Chem. Soc., 31, p. 870-4 (1988).

(7) I. L. Finar, and G. H. Lord, J. Chem. Soc., p. 3314 (1957).

(8) a) B. Castro, et al., Tetrahedron Lett., p.1219 (1975). b) J. M. Coste, N. Dufour, D. LeNouguen, and B. Castro, In Peptides: chemistry, struture and biology, Rivier, J. E. and Marrshall, G. R., (Eds.), ESCOM Science Publishers, 1990, pp. 885-888. c) J. M. Coste, N. Dufour, D Le-Nouguen, and B. Castro, Tetrahedron Letters, 31, 205-208 (1990). d) J. Jones, In The Chemical Synthesis of Peptides, Oxford University Press, New York, 1994.

(9) J. C. R. Barrans, Acad. Sci., 249, 1096 (1959).

(10) I. L. Finar, and K. E. Godfrey, J. Chem. Soc., p. 2293 (1954).

(11) I. L. Finar, and K. Utting, J. Chem. Soc., p. 4015 (1959).

Received on July 8, 1999 